\title{
HIGHWAY AND RAILWAY INFRASTRUCTURE, REAL INCOME AND STRUCTURAL BREAKS
}

\begin{abstract}
Infrastructure systems affect economic development directly or indirectly depending on their structure, type, quality and quantity. Transportation infrastructure is one of the most important types of infrastructure systems since the improvements in transportation infrastructure has tangible and intangible benefits to economy such as reducing costs, increasing productivity and outputs. Therefore, investment in transportation infrastructure is important, while this contributes to economic development directly by lowering transportation costs and facilitating trade. All sectors include services provided by transport infrastructures are fundamental to economic activities due to enhanced mobility of goods and services. This reflects that the whole economy is related to transportation and the relationship between transportation infrastructure and economic growth has been analyzed in many studies by using different methodological approaches. The aim of this paper is to analyze the relationship between the transportation infrastructure and economic growth in Turkey for the period 1970-2006. Empirical analysis from cointegration tests with and without structural break show that the long run affects of real income, highway length, railway length and labor force on real income vary within tests with respect to sign and significance. However, the relationship between share of transportation in fixed capital investments and real income is positive and significant for all tests including dynamic OLS. This shows that private and public policies toward transportation infrastructure should target investments and improvements in the quality of transportation, not quantity.

Keywords: Highway infrastructure, Railway infrastructure, Cobb-Douglas production function, Co-integration tests, Structural breaks, Transportation investments, Jel Classification: C54, E23, H54, L92
\end{abstract}

\section{INTRODUCTION}

Infrastructure systems affect development directly or indirectly depending on their structure, type, quality and quantity. Transportation infrastructure is one of the most important types of infrastructure since the improvements in transportation infrastructure has tangible and intangible benefits to economy such as reducing costs, increasing productivity and outputs.

Investment in transportation infrastructure contributes to economic development directly by lowering transportation costs and facilitating trade. Services provided by transport infrastructure are fundamental to economic activities due to enhanced mobility of goods and services. Lower costs and ease of access to markets causes a range of sectoral, spatial and regional developments from the private sector point of view

\footnotetext{
${ }^{1}$ Mehmet Aldonat Beyzatlar, Dokuz Eylül University, Faculty of Business, Department of Economics. Corresponding Author. E-mail: mehmet.beyzatlar@ deu.edu.tr

${ }^{2}$ Yeşim Rabia Kuştepeli, Dokuz Eylül University, Faculty of Business, Department of Economics.
} 
(Aschauer, 1989; Munnell, 1990; Gramlich, 1994; Bougheas, et al. 2000). Improvements in transportation cause increased accessibility, specialization and market expansion thus causing increasing returns to scale and spatial agglomeration effects as well as innovation. As a result, total factor productivity and GDP growth increases (Bougheas et al., 2000; Lakshmanan, 2007). The effects of transportation infrastructure to economic development are argued to be more interpretable in developing countries rather than developed countries (Zhou, Yang, Xu and Liu, 2007).

The aim of this paper is to analyze the relationship between the transportation infrastructure and economic growth in Turkey for the period 1970-2006. Empirical analysis is carried through time series analysis; cointegration tests with and without structural breaks.

The rest of the paper is organized as follows: the second section provides the literature survey, while the third section consists of data and methodology and the fourth section shows the empirical results. The last part concludes the paper with interpretation of the findings and policy implications.

\section{LITERATURE SURVEY}

The relationship between transportation infrastructure and economic growth has been analyzed in many studies for regions, countries and continents by using production function or cost function approaches. The theoretical framework which argues that improvements in transportation infrastructure has positive effects on economic development, is supported with many empirical studies where transportation infrastructure is measured by highway lengths, railway lengths, transportation spending per capita and transportation capital such as water and sewer, electricity and gas, hospitals and passenger rail stations. These measures are selected according to the observed area (local, county or national). The improvement measures regarding economic development are generally per capita income, growth, investments (e. g. foreign direct investment, manufacturing industry), manufacturing costs, productivity, and rate of return, output, employment, and labor force. The evidence from empirical studies shows, in general, a positive relationship between transportation with all its components (investment, infrastructure) and development (productivity, economic growth, quality). There is a vast amount of literature on the relationship between transportation infrastructure and economic development. Therefore, Table A1 shows some selected studies with respect to infrastructure and development measures, observed area, period and results, while these studies are briefly summarized below.

Most of the research dealing with the economic effect of transport infrastructures has relied on the estimation of aggregated Cobb-Douglas production function. The initial novelty of including public capital as an input, along with labor and private capital, put aside many of the econometric problems that had been identified in the estimation of production functions, both at the firm level or on the aggregate. Therefore, in the first generation of studies on the effect of public infrastructure, the specification commonly used is a Cobb-Douglas production function estimated by OLS, despite the well-known econometric problems posed by this type of production function estimation (Griliches and Mairesse, 1998). 
Production function approach has been first used by the most known researcher of that topic, Aschauer, also the pioneer of the relationship between infrastructure and development. Aschauer (1989) investigates the effects of public capital on the productivity of private sector. The results indicate that the elasticity of private sector productivity with respect to public capital is positive. Munnell (1990) also finds a positive (elasticity of 0.35 ) relationship between transportation investment and private sector productivity. Munnell and Cook (1990) investigate the impact of highways on Gross State Product (GSP) where they show that the elasticity of GSP with respect to highways 0.06 on the positive side. Duffy-Deno and Eberts (1991), Eisner (1991), Garcia-Mila and McGuire (1992) and Moonmaw, et al. (1994) similarly obtain positive relationships between transport infrastructure and per capita income by using production function approach.

Jones (1990), Mofidi and Stone (1990) and Reynolds and Maki (1990) study the effects of highway spending per capita on three different development measures. Jones et al (1990) consider employment, income and investment whereas Mofidi and Stone (1990) takes manufacturing investments and employment into account and Reynolds and Maki (1990) investigate new manufacturing plants. First two studies' results are positive but the latter one's result is neutral. Singletary, et al. (1995), Grihfield and Panggabean (1995), Garcia-Mila, McGuire and Porter (1996) and Fernald (1999) show that increases in highways raise manufacturing industry employment and productivity growth.

Berndt and Hansson (1992), Lynde and Richmond (1993), Seitz (1993), Nadiri and Mamuneas (1994), Conrad and Seitz (1994) and Boarnet (1996; 1998) use cost function approach for the investigation of the relationship between transport measures and development for Sweden, United Kingdom, West Germany and USA. The common finding of these studies is that the effects of transport measures are cost reducing elements.

Bougheas, Demetriades and Mamuneas (2000) also introduce infrastructure as a cost reducing technology in their cross country study and according to their approach, transportation infrastructure cause specialization and long run growth. Infrastructure as a technology which reduces costs in the production of intermediate inputs has more impact rather than as an input in the production of final goods. Bougheas, et al. (2000) argue that variation across countries is an important criterion due to the lack of infrastructure in less developed countries and abundance of infrastructure in developed countries.

Boopen (2006) and Zhou, Yang, Xu and Liu (2007) examine the growth impact of transportation capital for developing countries of Africa and China, respectively. The former study uses a Cobb Douglass production function which regress total output on labor, physical capital and transportation capital. The findings show that investment in transportation capital is more productive than investment on average in Africa. The second paper investigates China with regional perspective. The correlation matrix for highways, growth and exports shows that highway construction has significant and positive effect on economic growth. The study also stresses that the quality and the quantity of transportation infrastructure is crucial in terms of its contribution to economic development. 


\section{DATA AND METHODOLOGY}

The data set for the analysis consists of three parts. The first part is infrastructure data (highway lengths in $\mathrm{km}$, railway lengths in $\mathrm{km}$, share of transport in fixed capital investment) which is obtained from the Canning database ${ }^{1}$ and Turkish State Railways and General Directorate of Highways. The second part, labor data (labor force) and the third part, economic measurement data, (real GDP per capita), are obtained from OECD database $^{2}$. All of the data is annual and covers the period 1970-2006.

In the light of the literature on the relationship between infrastructure and economic growth, a Cobb-Douglass production function model is used as the econometric model for this analysis:

$G D P_{t}=A_{t} \cdot H W_{t}^{\beta_{1}} \cdot R R_{t}^{\beta_{2}} \cdot L F_{t}^{\beta_{3}} \cdot T S_{t}^{\beta_{4}} \cdot U_{t}$

where GDP is the per capita GDP, A is total factor productivity, HW is the highway lengths in km, RRW is railway lengths in $\mathrm{km}$, LF is the labor force, TS is the transportation share in fixed capital investment and $U$ is the error term of the regression equation. To estimate and interpret the coefficients $\beta_{1}, \beta_{2}, \beta_{3}$ and $\beta_{4}$, the natural logarithms of both sides of the model is taken to get.

$\operatorname{lgd} p_{t}=a_{t}+\beta_{1} l h w_{t}+\beta_{2} l r r_{t}+\beta_{3} l l f_{t}+\beta_{4} l t s_{t}+u_{t}$

In line with the theory, we expect $\beta_{1}, \beta_{2}$, and $\beta_{4}$ to be positive. Increases in highways and railways in length and investment in transportation help the cost of production to fall and lead to a rise in output. $\beta_{3}$ could be positive or negative depending on the productivity of the labor force which depends on many factors such as education, human capital etc.

Time series analysis requires that the variables are stationary or not. For example, for cointegration tests the variables should be non-stationary and integrated of the same order because the tests may falsely give evidence of cointegration if one or more of the variables are stationary. The time series properties of the variables are determined by the use of ADF (Augmented Dickey-Fuller), Phillips-Perron and KPSS unit root tests. We use these three different tests to check the robustness of the results. ADF is more efficient in large samples whereas KPSS is in small samples. KPSS and ADF tests should support each other, if the fractional stationarity does not exist. The rejection frequency of the ADF test falls dramatically in the presence of a break in the cointegration vector (Gregory and Hansen, 1996b). In addition, auto-regressive process is suitable for ADF but moving average process fits Philips- Perron (PP) unit root test.

After the unit root tests, we conduct the Engle-Granger two-step cointegration test which does not take structural breaks into account. The Engle-Granger test applies ADF unit root test on the residuals of the equation with variables that are integrated of the same order. If the residuals are stationary, then the variables in question are cointegrated. Johansen-Juselius cointegration test is also performed to compare and add a new

\footnotetext{
${ }^{1}$ http://www.hsph.harvard.edu/faculty/david-canning/
} 
dimension to the results of Engle-Granger two-step cointegration test. Johansen-Juselius approach provide the possibility of multiple cointegration relationships. This test offers trace and maximum Eigen-value statistics for the rejection of the hypotheses.

As the data covers 37 years, the existence of structural breaks should also be investigated to make the analysis more robust. The Zivot-Andrews unit root test takes the structural breaks into account endogenously. This unit-root test has three models, which are shown below:

Model $A: y_{t}=\hat{\mu}^{A}+\hat{\theta}^{A} D U_{t}(\lambda)+\hat{\beta}_{t}^{A}+\hat{\alpha}^{A} y_{t-1}+\sum_{j=1}^{k} \hat{c}^{A} \Delta y_{t-j}+\hat{e}_{t}$

Model $B: y_{t}=\hat{\mu}^{B}+\hat{\gamma}^{B} D T_{t}(\lambda)+\hat{\beta}_{t}^{B}+\hat{\alpha}^{B} y_{t-1}+\sum_{j=1}^{k} \hat{c}^{B} \Delta y_{t-j}+\hat{e}_{t}$

Model $C: y_{t}=\hat{\mu}^{C}+\hat{\theta}^{C} D U_{t}(\lambda)+\hat{\gamma}^{C} D T_{t}(\lambda)+\hat{\beta}_{t}^{C}+\hat{\alpha}^{C} y_{t-1}+\sum_{j=1}^{k} \hat{c}^{C} \Delta y_{t-j}+\hat{e}_{t}$

Zivot-Andrews actually follow the Perron's ADF testing strategy and use during testing the unit root regression equations. Their three model unit root testing differs with the exception of $D T_{B}$ is to increase in absolute value the magnitude of the t statistic for testing $\alpha^{i}=1$. According to model $\mathrm{A}$ for a one time change in the level of the series, which is called crash model by Perron, this model detects the mean break, i.e the change in the intercept of the trend function at break time. Model B covers the change in the slope of the trend function occurring at break time, which is called changing growth by Perron, detecting the slope break. The last model $\mathrm{C}$ detects changes in both mean and slope at the break time. In these models, DU and DT are dummy variables that respectively capture a break in mean and slope occurring at the break time. The break point is TB where $D U=1$ if $t>T B$, and zero otherwise. DT is equal to $(t-T B)$, if $(t>T B)$ and zero otherwise. The null hypothesis is rejected if the coefficient is statistically significant. Each model is estimated by ordinary least squares (OLS) with the break fraction $\lambda=T B / T$. For each value of $\lambda$, the number of extra regressors, $\mathrm{k}$ is determined using the model selection criterions and the t-statistics for testing $\alpha=1$ is computed.

Based on the results of this test, the long run relationship between the relevant variables is tested by the Gregory-Hansen cointegration test. The null hypothesis of Gregory-Hansen cointegration test is similar to the Engle-Granger test and the effect of an unknown structural break year is included by three types of models which are; shift in intercept (model $\mathrm{C}$ as level shift), shift in trend (model C/T as level shift with trend) and both trend and intercept shifts (model $\mathrm{C} / \mathrm{S}$ as a regime shift).

Standard cointegration model with trend and no structural break can be shown as:

$y_{1 t}=\mu+\beta_{t}+\alpha^{T} y_{2 t}+e_{t}$ where $t=1, \ldots, n ; y_{2 t}$ is I(1)and $e_{t}$ is $I(0)$ 
The motivation for this test is that there may be occasions in which the researcher may wish to test that cointegration holds over some (fairly long) period of time, but then shifts to a new 'long-run' relationship (Gregory and Hansen, 1996b). Gregory and Hansen treat the timing of this shift as unknown. The general kind of structural change considered in Gregory and Hansen (1996a) permits changes in the intercept $\mu$ and/or changes to the slope coefficients $\alpha$ but not the trend coefficient $\beta$.

To model the structural change, they define the dummy variable;

$$
\begin{aligned}
& \varphi_{t \tau}=0, \text { if } t \leq[n \tau] \\
& \varphi_{t \tau}=1, \text { if } t>[n \tau]
\end{aligned}
$$

where the unknown parameter $\tau \epsilon(0,1)$ denotes the (relative) timing of the change point, and [] denotes integer part. The level, level shift with trend and regime shift alternatives are:

Model $C: y_{1 t}=\mu_{1}+\mu_{2} \varphi_{1 \tau}+\alpha^{T} y_{2 t}+e_{t}$

$\operatorname{Model}^{C} /_{S}: y_{1 t}=\mu_{1}+\mu_{2} \varphi_{1 \tau}+\beta_{t}+\alpha_{1}{ }^{T} y_{2 t}+\alpha_{2}{ }^{T} y_{2 t} \varphi_{t \tau}+e_{t}$

Model ${ }^{C} /_{T}: y_{1 t}=\mu_{1}+\mu_{2} \varphi_{1 \tau}+\beta_{1} t+\beta_{2} t \varphi_{t \tau}+\alpha_{1}{ }^{T} y_{2 t}+\alpha_{2}{ }^{T} y_{2 t} \varphi_{t \tau}+e_{t}$

In this case $\mu_{1}, \alpha_{1}$ and $\beta_{1}$ are the intercept, slope coefficients and trend coefficient respectively before the regime shift and $\mu_{2}, \alpha_{2}$ and $\beta_{2}$ are the corresponding coefficients changes after the break. For each $\tau$, the above models are estimated by OLS, yielding the residuals $e_{t}$. From these residuals, the ADF test statistics and the Phillips' (1987) test statistics $Z_{\alpha}(\tau), Z_{t}(\tau)$ are estimated. $Z_{\alpha}(\tau)$ or $Z_{t}(\tau)$ statistics are acquired at the breaking point where the minimum ADF is found. Next, the null hypothesis of no co-integration is tested by using the smallest values of these statistics in the possible presence of breaks.

After Gregory-Hansen cointegration test, break years are used to estimate the coefficients by Stock-Watson (1993) Dynamic OLS model:

$X_{t}=\alpha_{0}+\alpha_{1} Y_{t}+\alpha_{2} D 1_{t}+\alpha_{3}\left(D 2_{t} Y_{t}\right)+\alpha_{4} \Delta Y_{t-1}+\alpha_{5} \Delta Y_{t+1}+u_{t}$ 
The dummy variables D1 and D2 are determined according to the break years. As there are four independent variables in this study, the Stock-Watson Dynamic OLS model becomes:

$$
\begin{array}{rl}
g d p_{t}=\alpha_{0}+\alpha_{1} & h w_{t}+\alpha_{2} D 1_{t}+\alpha_{3}\left(D 2_{t} h w_{t}\right)+\alpha_{4} \Delta h w_{t-1}+\alpha_{5} \Delta h w_{t+1}+\alpha_{6} r r_{t} \\
& +\alpha_{7}\left(D 3_{t} r r_{t}\right)+\alpha_{8} \Delta r r_{t-1}+\alpha_{9} \Delta r r_{t+1}+\alpha_{10} l f_{t}+\alpha_{11}\left(D 4_{t} l f_{t}\right) \\
& +\alpha_{12} \Delta l f_{t-1}+\alpha_{13} \Delta l f_{t+1}+\alpha_{14} t s_{t}+\alpha_{15}\left(D 5_{t} t s_{t}\right)+\alpha_{16} \Delta t s_{t-1} \\
& +\alpha_{17} \Delta t s_{t+1}+u_{t}
\end{array}
$$

\section{EMPIRICAL RESULTS}

\subsection{Unit Root and Cointegration Testing without Structural Break}

The results of unit root test (ADF, PP, and KPSS) are shown in Table 1. According to the ADF and PP tests, all of the variables have one unit root (i.e. integrated of order one, I (1)), but KPSS test signals that the effect of structural breaks should be examined. For the analysis without structural breaks, we conclude that all variables are I (1).

Table 1: Unit-Root Tests

\begin{tabular}{|c|c|c|c|c|c|}
\hline Unit Root Test & $l g d p$ & $l h w$ & $l r r$ & llf & Lts \\
\hline ADF & $-2,78^{* *}$ & $0,01 * *$ & $-1,99 * *$ & $-1,86^{* *}$ & $-2,39 * *$ \\
\hline PP & $-20,15$ & $-0,74 * *$ & $-2,02 * *$ & $-1,63 * *$ & $-2,28 * *$ \\
\hline KPSS & $0,72 * *$ & $0,45^{*}$ & $0,69 * *$ & $0,72 * *$ & $0,71^{* *}$ \\
\hline
\end{tabular}

Note: ${ }^{*},{ }^{* *}$, and ${ }^{* * *}$ indicate the rejection of null hypothesis as stationary at $10 \%, 5 \%$ and $1 \%$ significance levels, respectively.

The long run relationship between real GDP per capita, transportation measures and labor force is tested with Engle-Granger (1987) two step modeling where the results are shown in Table 2. According to the first step, the ADF test for the residuals (unit root test) signals that the null hypothesis that the residuals have a unit root is rejected. This means that there is no long run relationship between the variables. The possibility of spurious results is ruled out as R-squared is less than the Cointegration Regression Durbin Watson (CRDW). The possibility of cointegration in the long run increases when CRDW is greater than R-squared.

The second step is the error correction mechanism (ECM), where the first differences of the variables and the residuals in period $t-1$ are included in the estimation. The magnitude of the residual $e_{t-1}$ is the derivation from long-run equilibrium in period (t-1). The coefficient of residuals in period (t-1) is found to be $-0,132$, which indicates that the ECM is working and there is a short run relationship between the variables. All of the independent variables have positive coefficients with only the share of transport in fixed capital investment being statistically significant. 
Table 2: Engle-Granger 2-Step Cointegration Test

\begin{tabular}{|c|c|c|c|}
\hline \multirow[t]{7}{*}{$1^{\text {st }}$ Step } & Regressor & Coefficient & T-Stat \\
\hline & Constant & $-12,146$ & $-0,753$ \\
\hline & $l r r$ & 4,227 & $3,277 * * *$ \\
\hline & lhw & 3,918 & $1,848^{*}$ \\
\hline & llf & 3,071 & $11,443 * * *$ \\
\hline & lts & 0,327 & $2,938 * * *$ \\
\hline & \multicolumn{3}{|c|}{$\mathrm{R}^{2}=0,984$ and $\mathrm{CRDW}=1,144$} \\
\hline \multirow[t]{8}{*}{$2^{\text {nd }}$ Step } & Regressor & Coefficient & T-Stat \\
\hline & Constant & 0,054 & $5,143 * * *$ \\
\hline & $d l r r$ & 0,553 & 0,574 \\
\hline & $d l h w$ & 0,379 & 0,339 \\
\hline & dllf & 0,272 & 0,601 \\
\hline & dlts & 0,224 & $3,511 * * *$ \\
\hline & $\operatorname{res}(-1)$ & $-0,132$ & 1,231 \\
\hline & \multicolumn{3}{|l|}{ ADF: $-3,72$} \\
\hline
\end{tabular}

Note: ${ }^{* * *}$, and ${ }^{* * *}$ indicate the rejection of null hypothesis at $10 \%, 5 \%$ and $1 \%$ significance levels, respectively. Critical values are based on MacKinnon (1991) and at 5\% significance level are 4.413; models include constant and no trend; $k$ is the lag length used in the test for each series and number of lags are determined according to the AIC and given in parenthesis.

After determining the appropriate lag length by Akaike Information Criterion (AIC) and Schwarz Bayesian Criterion (SBC), Johansen-Juselius cointegration procedure is applied on the variables. Table 3 below reports the results of this test. 
Table 3: Johansen-Juselius Cointegration Test

\begin{tabular}{|c|c|c|}
\hline \multicolumn{3}{|c|}{ Trace Test } \\
\hline Null & Alternative & Stat \\
\hline $\mathrm{r}=0$ & $\mathrm{r} \geq 1$ & $135,090^{* * *}$ \\
\hline $\mathrm{r} \leq 1$ & $\mathrm{r} \geq 2$ & $79,126^{* * *}$ \\
\hline $\mathrm{r} \leq 2$ & $\mathrm{r} \geq 3$ & $44,995^{* *}$ \\
\hline \multicolumn{3}{|c|}{ Maximum Eigen-value Test } \\
\hline $\mathrm{Null}$ & Alternative & Stat \\
\hline $\mathrm{r}=0$ & $\mathrm{r} \geq 1$ & $55,964^{* * *}$ \\
\hline $\mathrm{r} \leq 1$ & $\mathrm{r} \geq 2$ & $34,131^{* *}$ \\
\hline $\mathrm{r} \leq 2$ & $\mathrm{r} \geq 3$ & $26,245^{* *}$ \\
\hline
\end{tabular}

Note: ${ }^{* * *}$, and ${ }^{* * *}$ indicate the rejection of null hypothesis at $10 \%, 5 \%$ and $1 \%$ significance levels, respectively. List of the variables included in the cointegrated vector is lgdp,lhw, lrr, lts and intercept; and 37 observations from 1970 to 2006.

Maximum Eigen-value and trace test statistics reject the null hypothesis of no cointegration at all significance levels. Johansen-Juselius cointegration procedure suggests three cointegrating vectors at $5 \%$ and $10 \%$. However, maximum eigenvalue test indicates only one vector at $1 \%$. This long run relationship normalized for $\lg d p$ is estimated as:

$$
\lg d p=19,591(\text { lhw })-51,239(\text { lrr })+3,174(\text { llf })+3,35(\text { lts })
$$

$$
\text { (4.333) (-6.903) (1.252) (7.686) }
$$

The t-values in parentheses show that except railway length all of the variables affect real GDP per capita positively, with the exception of the coefficient of labor force being statistically insignificant.

\subsection{Unit Root and Cointegration testing with Structural Break}

To investigate the possibility of structural breaks, Zivot and Andrews (1992) test is applied over the period 1970-2006. The results presented in Table 4, reporting the minimum $t$ statistics and their corresponding break times, confirm the results of the previous tests that all series are I(1). Break points coincide with the Military Coup years; 1980 for GDP per capita and 1982 for highways. For railways, labor force and transportation share in fixed capital investment; break points are 1988, 1993 and 1994, respectively which seem to coincide with the economic crisis. 
Table 4: Zivot-Andrews Unit Root Test

\begin{tabular}{|c|c|c|c|c|c|}
\hline & $\lg d p$ & $l h w$ & $l r r$ & llf & Lts \\
\hline Break Year & 1980 & 1982 & 1988 & 1993 & 1994 \\
\hline$Y(t-1)$ & $\begin{array}{c}-0,39 \\
(-3,14)\end{array}$ & $\begin{array}{c}-0,61 \\
(-4,43)\end{array}$ & $\begin{array}{c}-0,58 \\
(-3,76)\end{array}$ & $\begin{array}{c}-0,84 \\
(-4,61)\end{array}$ & $\begin{array}{c}-1,28 * * \\
(-5,05)\end{array}$ \\
\hline $\mathbf{t}$ & $\begin{array}{c}0,04 \\
(2,72)\end{array}$ & $\begin{array}{l}0,001 \\
(1,72)\end{array}$ & $\begin{array}{l}0,001 \\
(2,56)\end{array}$ & $\begin{array}{l}0,014 \\
(4,65)\end{array}$ & $\begin{array}{l}0,028 \\
(4,64)\end{array}$ \\
\hline $\mathbf{B}(\mathbf{t})$ & $\begin{array}{c}-0,08 \\
(-1,61)\end{array}$ & $\begin{array}{c}0,036 * * * \\
(6,45)\end{array}$ & $\begin{array}{l}0,003 \\
(0,49)\end{array}$ & $\begin{array}{c}-0,08 * * * \\
(-5,56)\end{array}$ & $\begin{array}{c}-0,49 * * \\
(-5,12)\end{array}$ \\
\hline $\mathbf{D}(\mathbf{t})$ & $\begin{array}{c}0,03 \\
(0,99)\end{array}$ & $\begin{array}{c}-0,02 \\
(-4,79)\end{array}$ & $\begin{array}{c}-0,01 \\
(-1,67)\end{array}$ & $\begin{array}{c}0,04 \\
(3,11)\end{array}$ & $\begin{array}{c}-0,01 \\
(-0,07)\end{array}$ \\
\hline DT(t) & $\begin{array}{c}-0,02 \\
(-2,25)\end{array}$ & $\begin{array}{l}0,001 \\
(1,59)\end{array}$ & $\begin{array}{c}0,0001 \\
(0,2)\end{array}$ & $\begin{array}{l}-0,005 \\
(-4,34)\end{array}$ & $\begin{array}{l}-0,015 \\
(-1,93)\end{array}$ \\
\hline $\mathbf{k}$ & 0 & 0 & 0 & 4 & 4 \\
\hline
\end{tabular}

Note: ${ }^{* * *}$, and ${ }^{* * *}$ indicate the rejection of null hypothesis at $10 \%, 5 \%$ and $1 \%$ significance levels, respectively. Critical values at $1 \%, 5 \%$ and $10 \%$ significance level are $-5.57,-5.08$ and -4.82 respectively (Zivot and Andrews, 1992), $\mathrm{k}$ is the lag length used in the test for each series and selected criteria based on AIC, $t$ statistics of the related coefficients are given in parenthesis.

Gregory and Hansen (1996) extended the Engle-Granger cointegration test to allow for breaks in either just the intercept or both the intercept and trend of the cointegrating relationship at an unknown time. As stated by Gregory and Hansen (1996), their testing procedure is of special value when the null hypothesis of no cointegration is not rejected by the conventional tests. The results of this test (Table 5) shows that for all models there is evidence of a cointegration with the exception the results of $Z_{\alpha}^{*}$. 
Highway and railway infrastructure, real income ...

Table 5: Gregory-Hansen Cointegration test

\begin{tabular}{|c|c|c|c|c|c|c|}
\hline Model & ADF & $\begin{array}{c}\text { Break } \\
\text { Year }\end{array}$ & $Z_{t}^{*}$ & $\begin{array}{c}\text { Break } \\
\text { Year }\end{array}$ & $Z_{\alpha}^{*}$ & $\begin{array}{c}\text { Break } \\
\text { Year }\end{array}$ \\
\hline $\mathrm{C}$ & $-7,911 * * *$ & 1982 & $-14,596 * * *$ & 1985 & $-59,221$ & 1997 \\
\hline $\mathrm{C} / \mathrm{T}$ & $-8,777 * * *$ & 1994 & $-16,117 * * *$ & 1994 & $-59,255$ & 1981 \\
\hline $\mathrm{C} / \mathrm{S}$ & $-8,043 * * *$ & 1987 & $-14,491 * * *$ & 1985 & $-59,251$ & 1998 \\
\hline $\begin{array}{c}\text { Critical } \\
\text { Value }\end{array}$ & \multicolumn{7}{|c|}{$-6,840$} & $-88,471$ \\
\hline
\end{tabular}

Note: ${ }^{* * *}$, and ${ }^{* * *}$ indicate the rejection of null hypothesis at $10 \%, 5 \%$ and $1 \%$ significance levels, respectively. Critical values for $\mathrm{ADF}$ and $Z_{t}$ at $5 \%$ significance level is -6.84 , and for $Z_{\alpha}$ is -88.47 respectively (Gregory and Hansen, 1996).

We then proceed to Stock and Watson Dynamic OLS model shown in (13) to estimate the coefficients of cointegrated variables. The estimation results are presented in Table 6 . It can be seen that highway length and labor force has a negative and significant relationship with income while railway length affects it positively but the coefficient is not statistically significant. The coefficient of the share of transportation in fixed capital investment is both positive and significant as expected.

Table 6: Stock-Watson Dynamic OLS model

\begin{tabular}{|c|c|c|c|c|c|c|c|c|}
\hline & $\alpha_{1}$ & $\alpha_{3}$ & $\alpha_{6}$ & $\alpha_{7}$ & $\alpha_{10}$ & $\alpha_{11}$ & $\alpha_{14}$ & $\alpha_{15}$ \\
\hline Coeff. & $-2,38$ & 5,75 & 0,397 & $-12,96$ & $-0,27$ & 1,37 & 0,29 & $-0,12$ \\
\hline T-stat & $-2,184 * *$ & 1,413 & 0,303 & $-3,965 * * *$ & $-0,570$ & $1,827 *$ & $3,286 * * *$ & $-0,787$ \\
\hline
\end{tabular}

Note: The numbers in parentheses are the t-statistics for the. *,** and $* * *$ denotes the rejection of null that the corresponding coefficients are zero at $10 \%, 5 \%$ and $1 \%$ significance levels respectively. Dummy variables are as follows $\mathrm{D} 1_{\mathrm{t}}$ is 0 up to 1982 and 1 thereafter, and $\mathrm{D} 2_{\mathrm{t}}, \mathrm{D} 3_{\mathrm{t}}, \mathrm{D} 4_{\mathrm{t}}$ and $\mathrm{D} 5_{\mathrm{t}}$ are 0 up to 1994 and 1 thereafter.

\subsection{Overall Results}

When the empirical results from cointegration analysis without and with a structural break are considered, we see that the effects of highway length, railway length and labor force on real GDP per capita are contradictory. The results are summarized in Table 7. The effect of share of transportation in fixed capital investment is positive and significant all through. 
Table 7: Overall results

\begin{tabular}{|c|c|c|c|}
\hline \multirow{2}{*}{ Variables } & \multicolumn{2}{|c|}{$\begin{array}{r}\text { Cointegration Test } \\
\text { Without Structural Break }\end{array}$} & $\begin{array}{c}\text { Cointegration Test } \\
\text { With Structural } \\
\text { Break }\end{array}$ \\
\cline { 2 - 4 } & $\begin{array}{c}\text { Engle-Granger } \\
\text { Test }\end{array}$ & $\begin{array}{c}\text { Johansen } \\
\text { Test }\end{array}$ & $\begin{array}{c}\text { Stock-Watson } \\
\text { DOLS Model }\end{array}$ \\
\hline Highway length & + & $+^{*}$ & $-^{*}$ \\
\hline Railway length & + & $-^{*}$ & $+^{*}$ \\
\hline Labor force & + & + & $+{ }^{*}$ \\
\hline $\begin{array}{c}\text { Share of transportation } \\
\text { in fixed capital } \\
\text { investment }\end{array}$ & $+{ }^{*}$ & & \\
\hline
\end{tabular}

\section{CONCLUSION}

This paper analyzes the relationship between the transportation infrastructure and economic growth in Turkey for the period 1970-2006. In order to determine the features of this relationship, cointegration tests with and without structural breaks are applied through time series dimension. The results obtained rom Engle-Granger, JohansenJuselius, Gregory-Hansen and Stock-Watson procedures show that while the effects of highway length, railway length and labor force on real income per capita vary across tests with respect to sign and statistical significance, the effect of share of transportation in fixed capital investment is positive and significant for all tests.

These results can be interpreted as follows. The amount and type of investment in transportation rather than length of infrastructure (highways and railways), is crucial for increasing real GDP per capita. As an example, public investment on highway infrastructure in Turkey was on average $2.36 \%$ of the government budget for 1970-2005. Highway length in kilometers increased from 59,000 kms in 1970 to $61,000 \mathrm{kms}$ in 2005 (Kuştepeli, Gülcan, Akgüngör, 2008). The effects of transportation on real economic activities in manufacturing and service based sectors have visible benefits such as time consumption in shipping of both raw materials, semi-finished goods and produced goods. In that sense, private and public policies toward transportation infrastructure should target investments and improvements in the quality and quantity of transportation.

More generally, the results indicate that there is a (positive) relationship between the transportation infrastructure and real GDP per capita. Models designed to assess this relationship should be formed in a scrutinized manner in terms of economic theory, econometric and empirical tools. 
Future research should be directed at explaining transportation infrastructure effects on different measures more directly related to up-to-date issues such as innovation performance, social network analysis, and online economic activities. Regional and national properties such as geographical characteristics, information systems play an important role and thus should be taken into account. Applying econometric methodology with cross-section dimension could supply more comparable results for policy implications; however this would only be possible whenever statistical institutions produce consistent time series data across countries.

\section{REFERENCES}

[1] Aschauer, D.A., (1989). Is public expenditure productive?" Journal of Monetary Economics, 23, pp: 177-200.

[2] Aschauer, D.A., (1990). Highway Capacity and Economic Growth. Economic Perspectives, Vol. 14, No.5 4-24.

[3] Berndt, E. R., and Hansson, B., (1992). Measuring the contribution of public infrastructure capital in Sweden" Scandinavian Journal of Economics 94, pages 151-68

[4] Boarnet, M.G., (1996). The direct and indirect economic effects of transportation infrastructure" Working Paper No. 340, University of California Transportation Center, Berkeley

[5] Boarnet, M.G., (1998). Spillovers and locational effects of public infrastructure. Journal of Regional Science 38 (3): 381-400.

[6] Boopen, S., (2006). Transport Infrastructure and Economic Growth: Evidence from Africa Using Dynamic Panel Estimates. The Empirical Economics Letters, 5(1), pp 38-52.

[7] Bougheas, S., Demetriades, P.O., Theofanis, P. and Mamuneas, T.P., (May 2000). Infrastructure, Specialization, and Economic Growth" The Canadian Journal of Economics / Revue canadienne d'Economique, Vol. 33, No. 2, pp. 506-522

[8] Canning, D. and Fay, M., (1993). The Effect of Transportation Networks on Economic Growth. Columbia University, May

[9] Conrad, K., and H. Seitz., (1994). The economic benefits of public infrastructure. Applied Economics 26:303-11.

[10] Crihfield, J. B., and Panggabean, M. P. H., (1995). Is public infrastructure productive? A metropolitan perspective using new capital stock estimates. Regional Science and Urban Economics 25:607-30.

[11] Duffy-Deno, K. T. and Eberts, R.W., (1991). Public Infrastructure and Regional Economic Development: A Simultaneous Equations Approach. Journal of Urban Economics, Vol. 30, 329-343.

[12] Eisner, R., (1991). Infrastructure and Regional Economic Performance. New England Economic Review, Federal Reserve Bank of Boston, Sept/Oct, 47-58.

[13] Engle, R.F. and Granger, C.W.J., (1987). Cointegration and Error Correction: Representation, Estimation and Testing. Econometrica, Vol: 55, pp.251-276.

[14] Fernald, J. G., (1999). Roads to Prosperity? Assessing the Link between Public Capital and Productivity. the American Economic Review, 619-638.

[15] Garcia-Mila, T. and McGuire, T.J., (1992). The Contribution of Publicly Provided Inputs to States' Economies. Regional Sciences and Urban Economics, 22, 229-241.

[16] Garcia-Mila, T., McGuire, T., and Porter, R.H., (1996). The effect of public capital in statelevel production functions reconsidered. The Review of Economics and Statistics 78 (February): 177-80

[17] Granger, C.W.J. (1986). Developments in the Study of Cointegrated Economic Variables. Oxford Bulletin of Economics and Statistics, Vol: 48, pp. 213-228. 
[18] Gramlich, E. M., (1994). Infrastructure Investment: A Review Essay. Journal of Economic Literature 32: 1176-1196.

[19] Gregory, A. W. and Hansen, B. E., (1996a). Residual-Based Tests for Cointegration in Models with Regime Shifts. Journal of Econometrics, Vol: 70, pp. 99-126.

[20] Gregory, A. W. and Hansen, B. E., (1996b). Tests for Cointegration in Models with Regime and Trend Shift. Oxford Bulletin in Economics and Statistics, 58, 3.

[21] Grilliches, Z. and Mairesse, J., (1998). Production functions: the search for identification. in S. Strom, ed., Econometrics and Economic Theory in the 20th Century, (Cambridge, Cambridge University Press), pp. 169-203.

[22] Haughwout, A.F., (1999). Regional fiscal cooperation in metropolitan areas: An exploration" Journal of Policy Analysis and Management 18 (4): 579-600.

[23] Johansen, S. and Juselius, K., (1990). Maximum likelihood estimation and inference on cointegration with applications to the demand for money" Oxford Bulletin of Economics and Statistics, 52, 169-210

[24] Jones, B. D., (1990). Public policies and economic growth in the American states. Journal of Politics 52: 219-233.

[25] Kuştepeli, Y., Gülcan, Y., and Akgüngör, S. (2008). Transportation Expenditures, Growth and International Trade. Dokuz Eylül University, Faculty of Business, Department of Economics Discussion Paper, 08/03.

[26] Kwiatowski, D., Phillips, P.C.B., Schmidt, P. and Shin, Y., (1992). Testing the Null Hypothesis of Stationarity against the Alternative of a Unit Root. Journal of Econometrics, Vol: 54, pp. 159-178.

[27] Lakshmanan, T.R., (2007). The Wider Economic Benefits of Transportation: An Overview. OECD International Transport Forum, Joint Transportation Research Centre Discussion Paper, No: 2007-8, December.

[28] Lynde, C. and Richmond, J., (1993). Public Capital and Long-Run Cost in U.K. Manufacturing” The Economic Journal, 103, 880-893.

[29] Mackinnon, J. G., (1991). Critical Values for Cointegration Tests, Engle, R.F. and Granger, C.W.J. (Eds.), Long-Run Economic Relationship, Oxford, UK: Oxford University Press.

[30] Mofidi, A. and Stone, J.A., (1990). Do state and local taxes affect economic growth?. The Review of Economics and Statistics 72:686-691

[31] Moonmaw, R. L., Mullen, J. K. and Martin, W., (1995). The interregional impact of infrastructure capital. Southern Economic Journal 61 (January): 830-45.

[32] Munnell, A.H., (1990). Why Has Productivity Declined? Productivity and Public Investment", New England Economic Review, Jan. / Feb., 3-22.

[33] Munnell, A.H. and Cook, L.M., (1990). How does Public Infrastructure Affect Regional Economic Performance", New England Economic Review, Sep./Oct., 11-32.

[34] Nadiri, M.I. and Mamuneas, T.P., (1994). The Effect of Public Infrastructure and R\&D Capital on the Cost Structure and Performance of U.S. Manufacturing Industries. the Review of Economics and Statistics, Vol 76 (1), 1994, 22-37.

[35] Reynolds, P.D. and Maki, W., (1990). U.S. regional characteristics, new firms, and economic growth" Working paper, University of Warwick, UK

[36] Seitz, H., (1993). A dual economic analysis of the benefits of the public road network", Annals of Regional Science 27: 223-39

[37] Singletary, L., Henry, M., Brooks, K. and London, J., (1995). The impact of highway investment on new manufacturing employment in South Carolina: A small region spatial analysis The Review of Regional Studies 25 (summer): 37-55.

[38] Stock, J. and Watson, M.W., (1993). A Simple Estimator of Cointegrating Vectors in Higher Order Integrated Systems. Econometrica, Vol. 61, 783-820

[39] Zhou, J., Yang, L., Xu, Y., Liu, C., (2007). The economic performance of transportation infrastructure: an empirical study on the recent development of China. World Transactions on Engineering and Technology Education UICEE, Vol.6, No.1, 2007, pp 193-197. 
[40] Zivot, E. and Andrews, D.W.K., (1992). Further Evidence on the Great Crash, the Oil-Price Shock, and the Unit-Root Hypothesis. Journal of Business and Economic Statistics, Vol: 10, No: 3, pp.251-70.

Supplementary bibliography is given in table A1.

\section{INFRASTRUKTURA DROGOWA I KOLEJOWA, DOCHÓD REALNY I ZMIANY STRUKTURALNE}

Systemy infrastruktury wpływają na rozwój gospodarczy bezpośrednio lub pośrednio, w zależności od ich struktury, rodzaju, jakości i ilości. Infrastruktura transportowa jest jednym z najważniejszych typów systemów infrastrukturalnych, gdyż jej poprawa przynosi zarówno materialne i niematerialne korzyści dla gospodarki, takie jak obniżenie kosztów, jak również zwiększenie wydajności. Dlatego inwestycje w infrastrukturę transportu są ważne, a to przyczynia się do rozwoju gospodarczego, bezpośrednio poprzez obniżenie kosztów transportu oraz ułatwienie handlu. Wszystkie sektory usługi świadczonych przez infrastrukturę transportową są podstawą działalności gospodarczej ze względu na zwiększoną mobilność towarów $\mathrm{i}$ usług. Zatem cała gospodarka jest związana $\mathrm{z}$ transportem, a relacja pomiędzy infrastrukturą transportową i wzrostem gospodarczym została przeanalizowana w wielu badaniach za pomocą różnych podejść metodologicznych. Celem tej publikacji jest analiza zależności występujących między infrastrukturą transportu a wzrostem gospodarczym w Turcji na przestrzeni lat 1970-2006. Analiza empiryczna przeprowadzona w oparciu o testy adaptacyjne uwzględniająca zarówno zmiany strukturalne jak i ich brak dowodzi, iż na dłuższą metę wpływ realnego dochodu, długości dróg publicznych, linii kolejowych i siły roboczej w kontekście rzeczywistych dochodów zmienia się w obrębie różnych testów w zależności od rodzaju wskaźników i ich znaczenia. Jednakże, zależność pomiędzy udziałem transportu w ustalonych inwestycjach kapitałowych a dochodem realnym jest korzystna i znacząca dla wszystkich wspomnianych testów. Wynika z tego, że zarówno prywatny jak i publiczny sektor infrastruktury transportu powinien obierać za główny cel inwestycje oraz poprawę jakości przewozu a nie jego ilość.

Słowa kluczowe: Infrastruktura drogowa, infrastruktura kolejowa, funkcja CobbDouglasa, testy kointegracyjne, zmiany strukturalne, inwestycje transportowe, klasyfikacje Jel: C54, E23, H54, L92

DOI: 10.7862/rz.2013.mmr.26

Tekst złożono w redakcji: wrzesień 2013

Przyjęto do druku: wrzesień 2013 
M. A. Beyzatlar, Y. R. Kuştepeli

\begin{tabular}{|c|c|c|c|c|c|c|c|c|c|c|c|c|}
\hline $\begin{array}{l}\stackrel{\tilde{E}}{\bar{Z}} \\
\stackrel{0}{0}\end{array}$ & + & + & + & + & + & + & + & ¿ & + & + & 之: & + \\
\hline 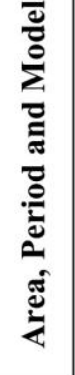 & 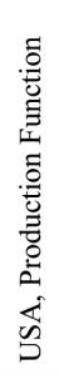 & 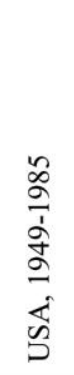 & 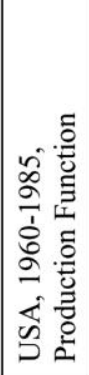 & 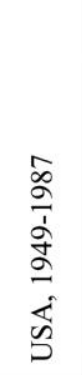 & 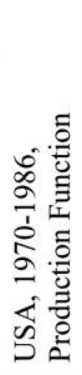 & 岕 & 吕 & 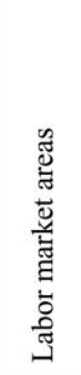 & 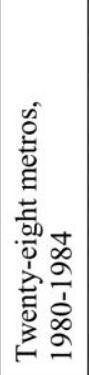 & 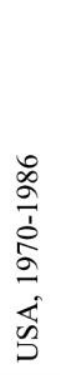 & 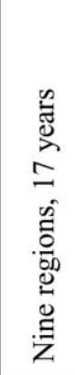 & 苂 \\
\hline 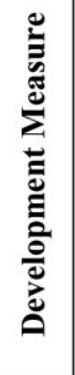 & 言 & 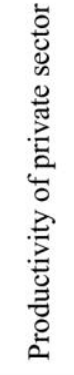 & 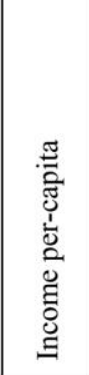 & 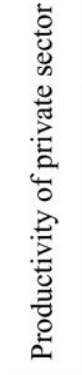 & 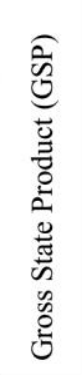 & 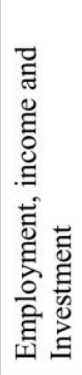 & 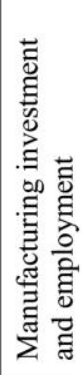 & 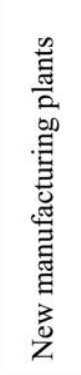 & 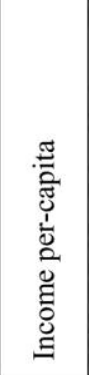 & 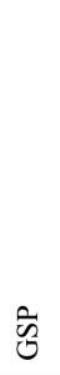 & 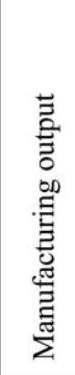 & 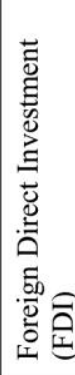 \\
\hline 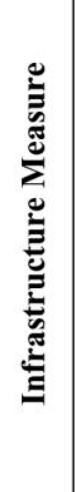 & 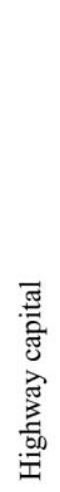 & 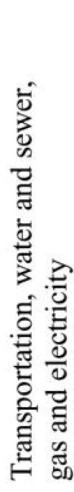 & 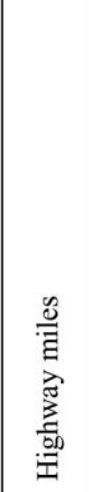 & 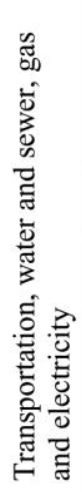 & 离 & 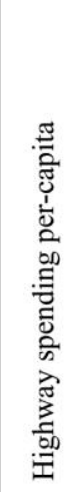 & 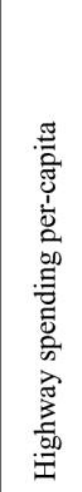 & 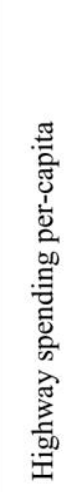 & 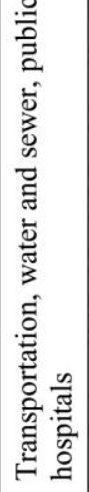 & 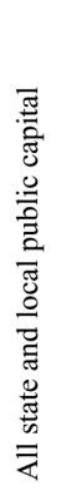 & 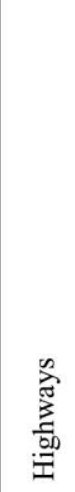 & 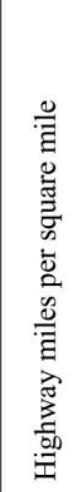 \\
\hline 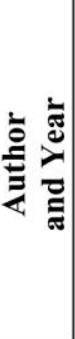 & $\begin{array}{l}\infty \\
\stackrel{\infty}{\Omega} \\
\stackrel{0}{\Xi} \\
0\end{array}$ & 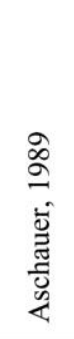 & 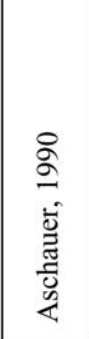 & 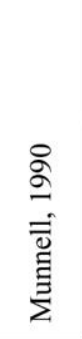 & 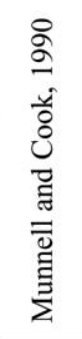 & 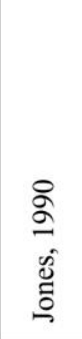 & 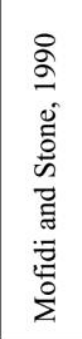 & 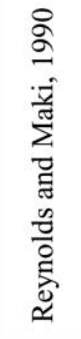 & 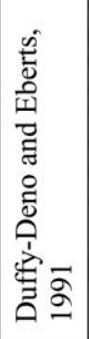 & 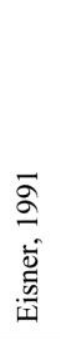 & 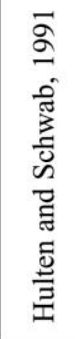 & 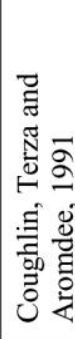 \\
\hline
\end{tabular}




\begin{tabular}{|c|c|c|c|c|c|c|c|c|c|c|c|c|c|}
\hline 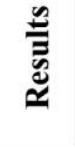 & + & ' & 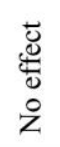 & + & + & + & + & 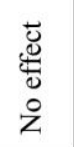 & 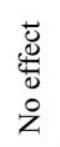 & + & 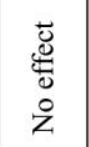 & ' & + \\
\hline 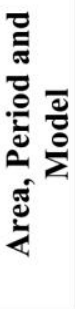 & 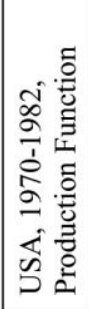 & 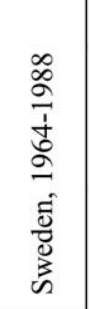 & 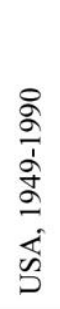 & 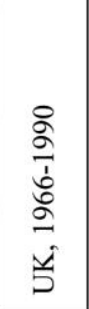 & 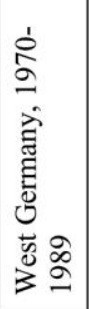 & 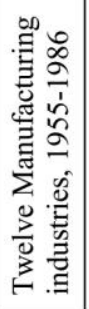 & 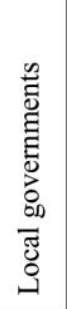 & 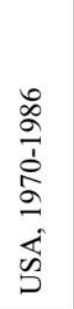 & 㟔 & 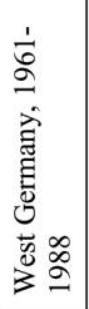 & 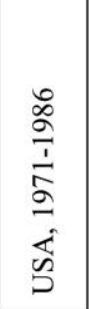 & 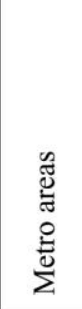 & 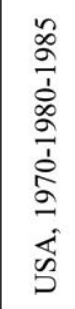 \\
\hline 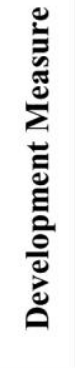 & ज्ञ & 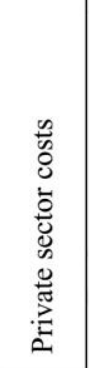 & 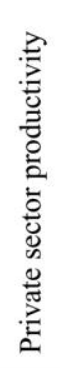 & 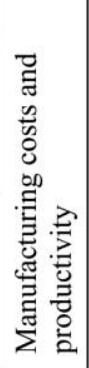 & 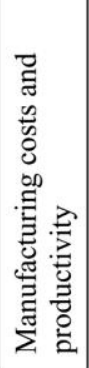 & 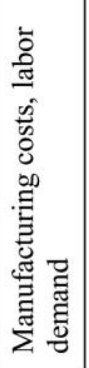 & 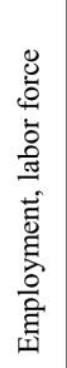 & $\overrightarrow{\hat{N}}$ & ज్ & 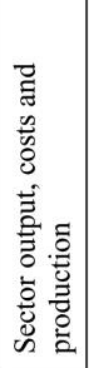 & 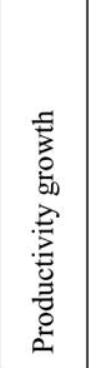 & 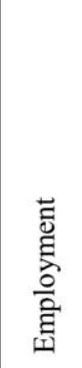 & 岕 \\
\hline 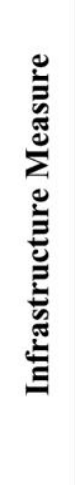 & 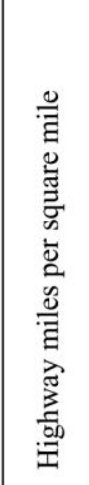 & 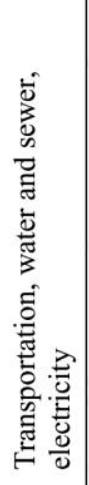 & 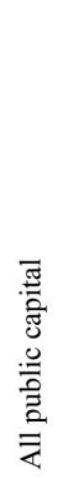 & 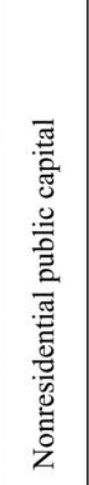 & 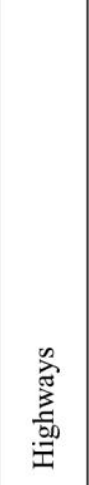 & 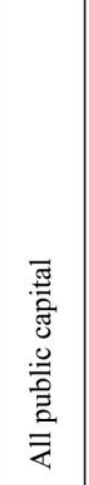 & 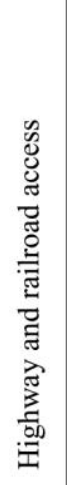 & 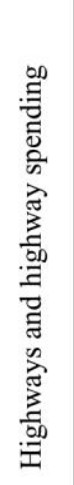 & 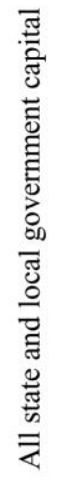 & 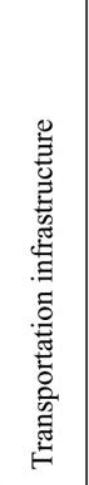 & 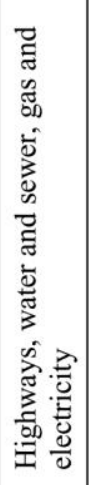 & 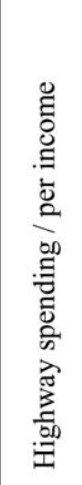 & 惫 \\
\hline 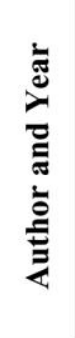 & 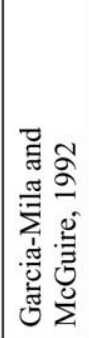 & 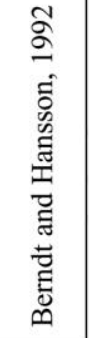 & 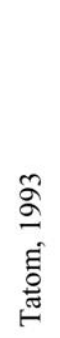 & 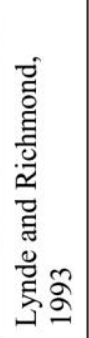 & $\begin{array}{l}\frac{n}{\sigma} \\
\frac{\tilde{N}}{0} \\
\tilde{n}\end{array}$ & 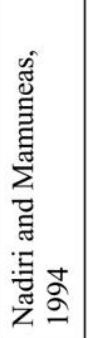 & 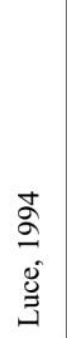 & 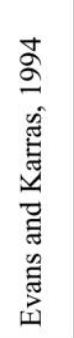 & 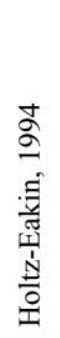 & 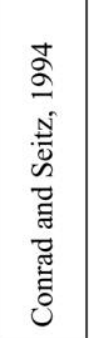 & 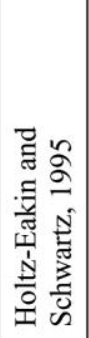 & 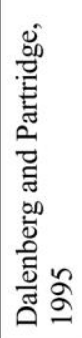 & 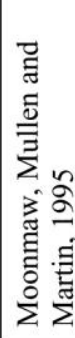 \\
\hline
\end{tabular}




\begin{tabular}{|c|c|c|c|c|c|c|c|c|c|c|c|c|c|}
\hline 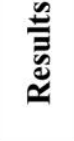 & 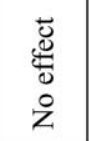 & + & + & + & + & + & + & + & + & + & + & 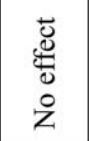 & + \\
\hline 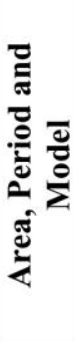 & 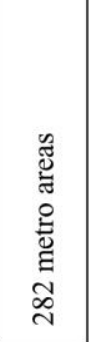 & 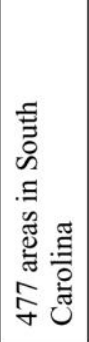 & 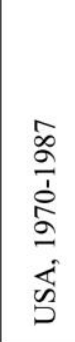 & 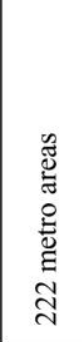 & 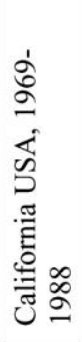 & 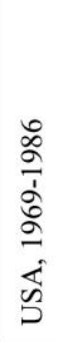 & 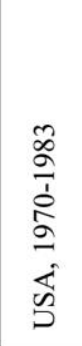 & 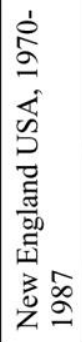 & 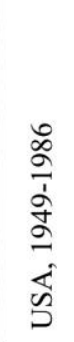 & 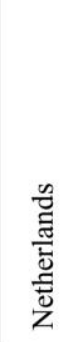 & 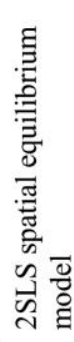 & 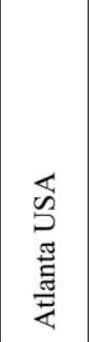 & 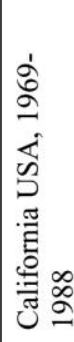 \\
\hline 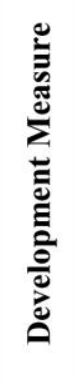 & 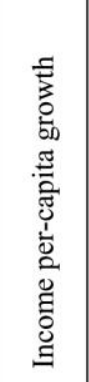 & 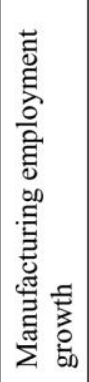 & 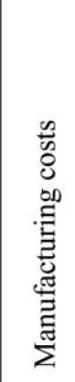 & 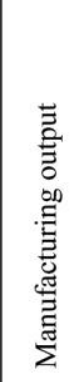 & 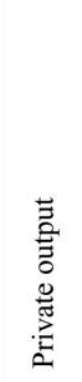 & 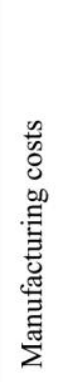 & 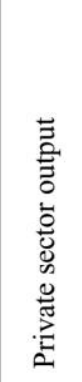 & 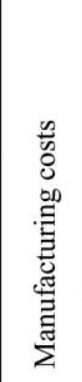 & 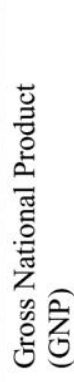 & 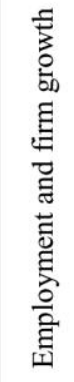 & $\begin{array}{l}\text { 言 } \\
\text { 言 }\end{array}$ & 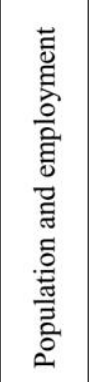 & 言 \\
\hline 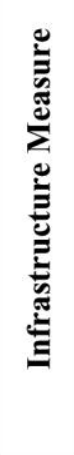 & 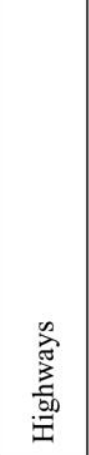 & 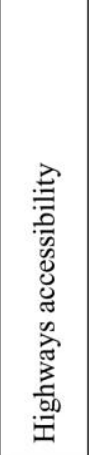 & 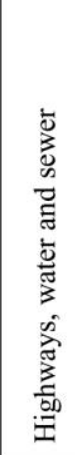 & 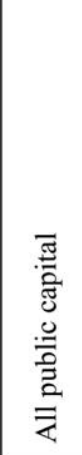 & 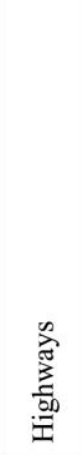 & 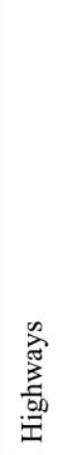 & 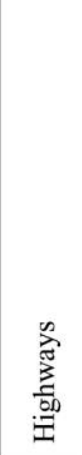 & 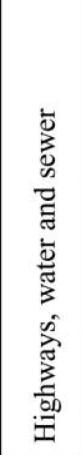 & 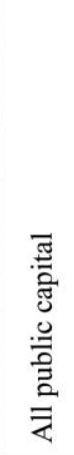 & 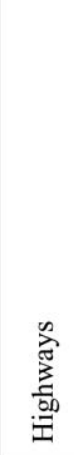 & 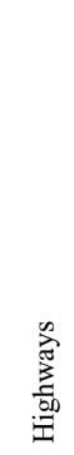 & 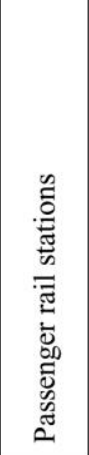 & 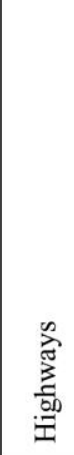 \\
\hline 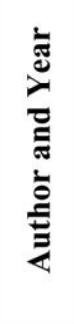 & 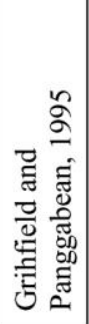 & 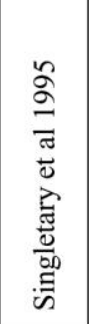 & 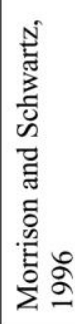 & 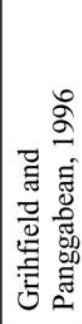 & 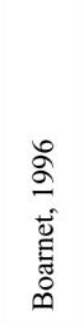 & 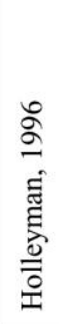 & 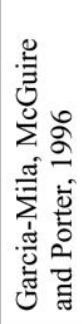 & 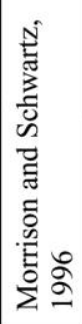 & 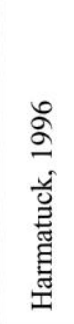 & 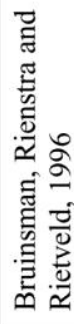 & 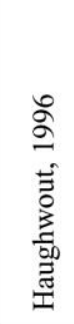 & 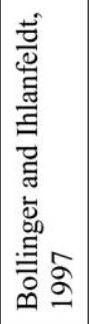 & 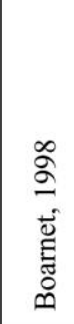 \\
\hline
\end{tabular}




\begin{tabular}{|c|c|c|c|c|c|c|c|c|c|}
\hline 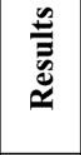 & + & + & + & + & + & + & + & + & + \\
\hline 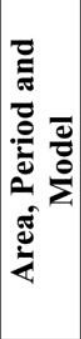 & 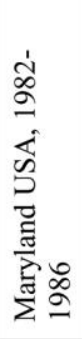 & 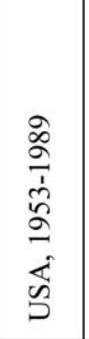 & 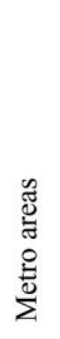 & 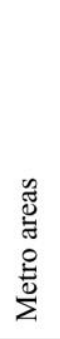 & 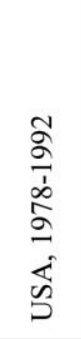 & 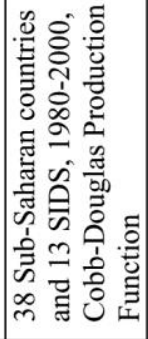 & 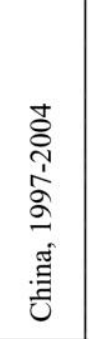 & 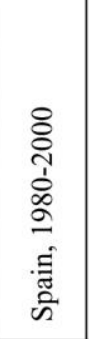 & 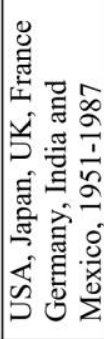 \\
\hline 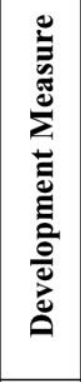 & 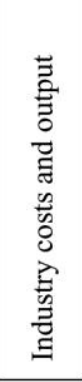 & 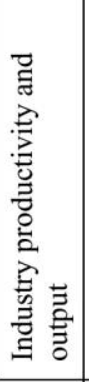 & 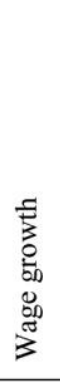 & 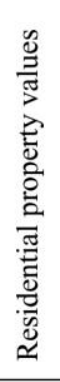 & 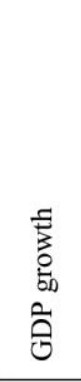 & जิ & 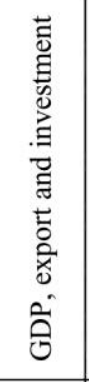 & 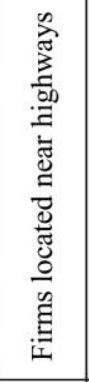 & 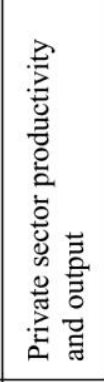 \\
\hline 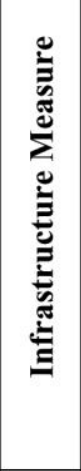 & 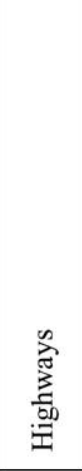 & 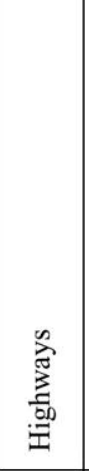 & 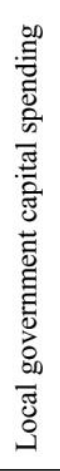 & 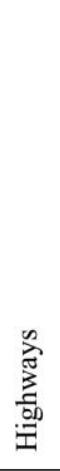 & 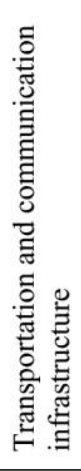 & 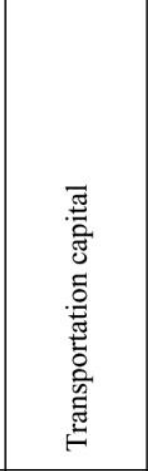 & 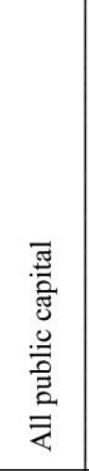 & 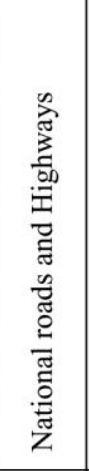 & 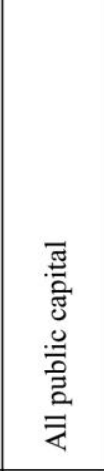 \\
\hline 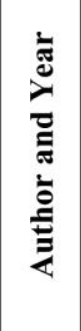 & 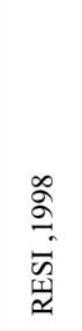 & 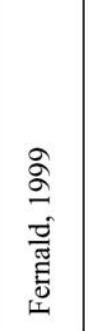 & 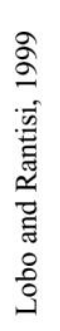 & 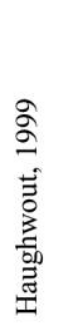 & 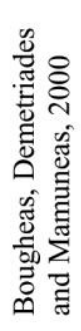 & 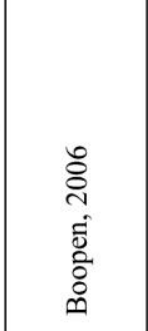 & 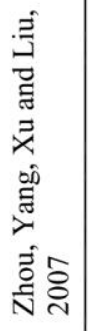 & 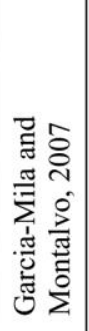 & 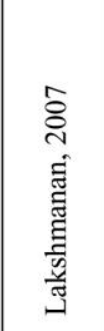 \\
\hline
\end{tabular}

